\title{
DOMESTIC COMPONENT LEVEL ASSESSMENT FOR A SALT FACTORY AND A SALT PRODUCTION
}

\author{
Irhan Febijanto ${ }^{1}$, Adiarso', Ati Widiati ${ }^{1}$, Dharmawan ${ }^{1}$, Dadang Rosadi ${ }^{1}$, Ermawan Darma \\ Setiyadi ${ }^{1}$, Gatyo Angkoso ${ }^{1}$, Karnadi ${ }^{1}$, Kusrestuwardhani ${ }^{1}$, Mohamad Soleh Iskandar ${ }^{1}$, Nurus \\ Sahari Laili ${ }^{1}$, Priyambodo Darmoyuwono ${ }^{1}$, M.Rosjidi ${ }^{1}$, Sunengsih ${ }^{1}$ \\ ${ }^{1}$ Centre for Assessment of Industry and Energy Process \\ Agency for the Assessment and Application of Technology \\ e-mail: irhan.febijanto@bppt.go.id
}

\begin{abstract}
The TKDN (Domestic Component Level) assessment of goods and services is a method to determine local manufacturers/industrie's capability to create quality products internationally standardized. This study assessed the salt factory's TKDN to increase the $\mathrm{NaCl}$ content, based on cost-based analysis stipulated at the Minister Industry Regulation No.16/M-IND/PER/2/2011. Meanwhile, the TKDN of salt production was assessed based on processbased analysis stipulated in Minister Industry Regulation No.16/2020. According to the cost-based analysis results, the goods and services at the pilot project stage had the TKDN value of $27.4 \%$. However, due to an increase in the number of main domestic components at the commercial stage, this value increased to $70.9 \%$. Meanwhile, according to the processed-based analysis results, the salt production had the same processes at the pilot project stage and commercial stages. The TKDN value of $85.5 \%$ was obtained for the two stages. The value is relatively high because the raw material is produced locally with the local labor and used work tools owned by the local industry. The cost-based analysis was found to be highly dependent on the equipment component's origin, while the process-based analysis depends on the origin of labor, works tool, and material owner.
\end{abstract}

Keywords: domestic component level; process-based analysis; costbased analysis; salt factory; salt product.

\section{INTRODUCTION}

Salt is one of the most important necessities in everyday life. In Indonesia, salt is mostly produced traditionally by smallholder farmers, as well as by industrial salt companies. However, in terms of quality, traditional salt production has not met health requirements, and the products have remained below quality, according to the Indonesian National Standard (Standard Nasional Indonesia/SNI) specifications No.140-76 [1]. below,

The types and uses of salt are outlined

1. Consumption salt is composed of $94.7 \%$ $\mathrm{NaCl}$ content (dry weight), with $2 \%$ Sulfate, Magnesium, and Calcium impurities, as well as other impurities (mud and sand), as well as water content below $7 \%$, and is divided into three types, as outlined below. (a) High grade or high-quality consumption salt has $97 \% \mathrm{NaCl}$ content, water content below $0.05 \%$, pure white color, as well as fine crystal grains, and is usually used for table salt, and in food seasoning, highquality food (including snack food, and instant noodles), sausage and cheese, as well as cooking oil industries.

(b) Medium grade or medium quality consumption salt comprises $94.7-97 \%$ $\mathrm{NaCl}$ as well as $3-7 \%$ moisture and is usually used for table salt and industries with tolerance for medium grade salt, for instance, soy sauce, tofu, animal feed.

(c) Low grade or low-quality consumption salt has $90-94.7 \% \mathrm{NaCl}$ content, $5-10 \%$ moisture content, dull-white color, and is used for salting fish as well as in agriculture. 
2. Industrial salt has comprised $97 \% \mathrm{NaCl}$ [2], Sulfate, and Calcium impurities below $0.5 \%$ and $0.2 \%$, respectively, as well as other impurities below $0.3 \%$ and $3-5 \%$ moisture content.

The previous study related to salt purification [3] using the deposition method has been conducted. In this study, a precipitating agent was added to the salt solution to precipitate impurities prior to the recrystallization process. was carried out. However, the research results show that the evaporation and recrystallization processes currently face several challenges and have therefore been unable to meet the industrial salt standard. Meanwhile, several other studies [4],[5] have succeeded in producing industrial salt according to SNI 06-0303-1989, using traditionally produced local salt.

Indonesia has a long coastline; however, the need for industrial salt consumption has not been fulfilled by local salt production. In terms of quality, the local salt production is highly dependent on the solar evaporation process and has been unable to meet industrial salt standards, as the weather factor has a significant influence. To overcome this national salt problem, a pilot project was conducted to produce industrial salt using raw materials from local salt. The salt factory's pilot project was built with a capacity of 40,000 tons/year. Subsequently, the factory was planned to be constructed for commercial purposes in salt centers to produce industrial salt with the technology previously tested in the pilot project.

\section{Salt Factory}

The processing of traditionally produced local salt into industrial salt comprises four stages.

1) Preparation of new materials for industrial salt.

2) Salt washing

3) Drying

4) Product packaging.

Figure 1 shows the factory's process sequences during the pilot project stage and commercial stages.

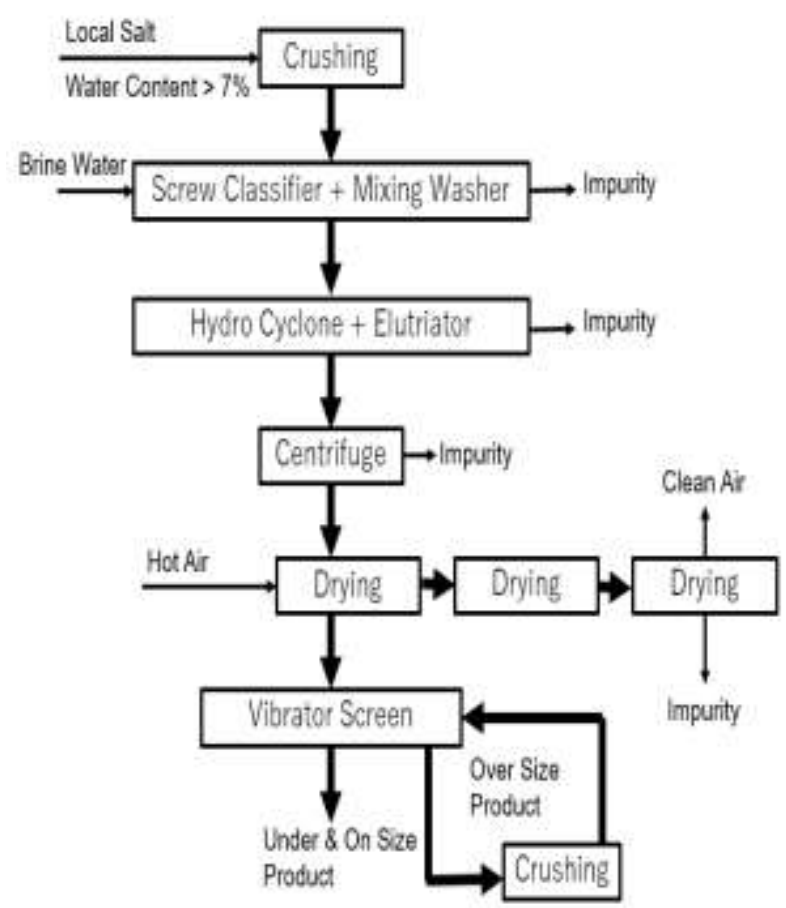

Figure 1. The Factory's Block Diagram Processes.

In the pilot project stage, the technology developed increases the local salt $\mathrm{NaCl}$ content from $88 \%$ to $98 \%$ and is to be implemented during the commercial stage.

Subsequently, the cost-based and processbased analyses were conducted to determine the salt factory and production's TKDN, respectively.

The cost-based analysis analyzes and calculates the TKDN of materials and salt factory services, performed on the 27 object's main components, civil buildings, human resources $(\mathrm{HR})$, and land.

Meanwhile, the process-based counterpart is used for TKDN analysis and calculation for salt products. This paper is the first to discuss the process-based analysis, as this method was released in 2020.

\section{Domestic Component Level (TKDN)}

The TKDN definition for goods and services are outlined below.

1. The amount of domestic components in goods, services, and a combination of goods and services.

2. Domestic production refers to goods/services, including design and engineering, produced/carried out by companies investing and producing in Indonesia, using a production/processing technique where the use of imported raw materials/components is possible. 
To assess a product's TKDN, three aspects, material, labor, and overhead, are usually evaluated. Material is assessed based on the country of origin or production location, employed labor is assessed based on nationality, while overhead refers to work tools/machines and other costs related to producing these goods/services.

The TKDN value of goods and services from salt factories and products is bound to be a parameter for the factorie's independence, both in component manufacturing, operation, and salt production. A rise in this value will therefore have the following impacts.

1) Increased use of domestically produced components related to the quality of domestic products or components created during the production process.

2) Increase/absorption of manpower/HR. In cases where a product or component's quality is successfully improved, an increase in the product's use is bound to occur. This impacts a rise in production and consequently influences labor/human resources absorption.

3) Foreign exchange savings from reduced purchases of imported products or components.

According to the previous study result, the TKDN calculations on the planning and development of Geothermal Power Plants/PLTP [6], Biogas Power Plants/PLTBg [7] as well as other power and industrial sectors, show a correlation between the TKDN value and reduced overhead, investment, as well as operating costs. A study by Hidayat et al, [8] showed an increase in the TKDN value in the national shipbuilding industry will increase competitiveness against ship production from other countries.

Thus, knowledge of salt factorie's TKDN shows the domestic industry's capacity to support production, as well as the dependence on imported components. This dependence has an impact on national resilience and the national industry's progress. Therefore, conducting TKDN analysis and calculation for an industry/product are the steps to identify dependency on imported parts/components and ascertain the domestic manufacturer's ability to support the industry. Efforts to increase this value also help impact local industrie's activation and foster new businesses with the ability to reduce component and overhead costs.
This paper, therefore, analyzes the TKDN of salt factories and products, using cost-based and process-based analyses under two stages, the pilot project and implementation, in Indonesia's salt centers. The salt factory being developed at the pilot project stage in Gresik, East Java, has a 40,000 ton/year capacity.

\section{METHODS}

For cost-based analysis, price data was obtained from a salt factory's feasibility study report to increase $\mathrm{NaCl}$ levels up to $98 \%$. Meanwhile, additional data and information to support calculations in the cost-based and process-based analysis were obtained from data search on the website and discussing results with the salt factory developer team. However, the main components, R\&D, human resources, civil buildings, and land prices, are not included in this paper to protect the salt factory development's confidentiality.

Subsequently, the TKDN analysis was performed using two methods based on the following regulations.

a) The Indonesian Minister of Industry Regulation Number: 16/MIND/PER/2/2011, regarding Provisions and Procedures for Cost-based Calculation of Domestic Component Levels [9].

b) The Indonesian Minister of Industry Regulation Number: Number 16 of 2020, regarding Processed-based Calculation of Domestic Component Level Value for Pharmaceutical Products [10].

Method a) analyzes the TKDN of the salt factory's main components at the pilot project as well as commercial stages and is also known as the cost-based analysis. This analysis also includes research and development costs in cases where a patent certificate or evidence of expenditure costs already exists. These costs are then calculated for the next five years because a patent certificate was issued. Figure 2 shows the TKDN cost-based analysis concept, where the prices of goods and services are separated. The domestic (KDN) and foreign components (KLN) were analyzed to two layers backwards from these goods and services components. Subsequently, each KDN and $\mathrm{KLN}$ component was sorted based on material, labor, and work tools. 


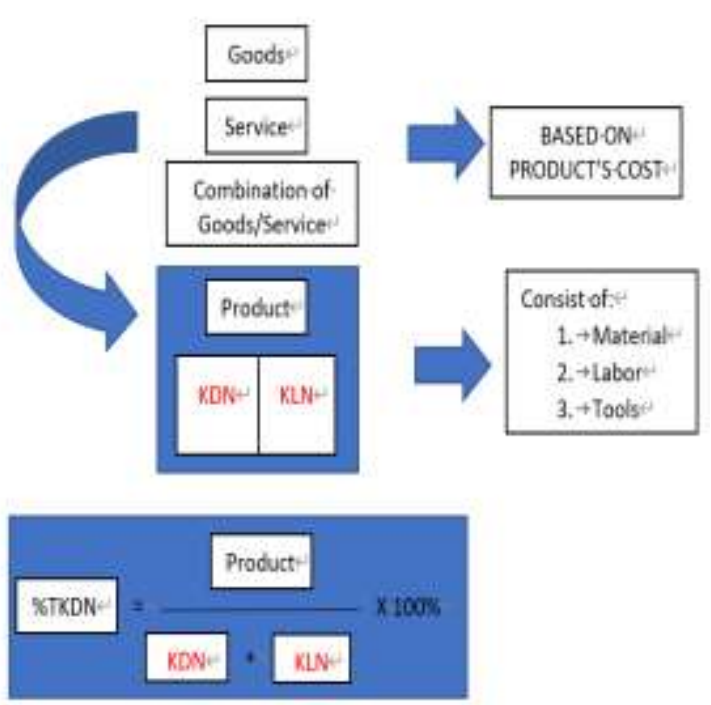

Figure 2. The TKDN Cost-Based Analysis Concept.

The TKDN of goods and services is the ratio between the goods and services from domestic components to the total counterpart from both domestic and abroad. In this study, the TKDN of domestic goods and services was calculated based on reducing the cost price of goods minus the foreign component of goods. Also, the price of goods already contains the goods and service's values.

The cost price refers to the cost incurred in producing goods and includes the following.

a. costs for direct material.

b. direct labor costs

c. factory indirect costs (factory overhead), excluding profits, company indirect costs (company overhead), and output taxes.

Meanwhile, the domestic components of goods were determined based on the criteria below.

a. for direct materials, based on the country of origin.

b. for work tools/facilities, based on ownership and country of origin, and

c. for labor, based on nationality.

Subsequently, the direct material and labor costs, as well as the indirect factory costs, were calculated up to the working location (factory/workshop) for the product concerned.

The cost-based analysis is carried out at the pilot project and commercial stages to assess the salt factory's TKDN.

After the pilot project was completed and the technology developed at this stage was confirmed to be able to increase $\mathrm{NaCl}$ content to $98 \%$, the technology is then implemented within factories in salt centers across Indonesia. An investigation regarding local manufacturer's ability to produce 27 main components of the salt factory was also conducted to implement this purpose.

To calculate material up to 2 layers backward of the main component, SUS316L's price was calculated using the equation below.

$H M=\sum_{i=1}^{26}$ Vol $x$ BJ $x$ Price
Where,
HM : Material Prices for 26 main components contained in SUS316L.
Vol : The total volume for the 26 main components $\left(\mathrm{m}^{3}\right)$
i : : The main component to $i$
BJ : $7,930\left(\mathrm{~kg} / \mathrm{m}^{3}\right)$
Price : $51,765(\mathrm{Rp} / \mathrm{kg})$

The TKDN value of goods and services from the main components was then calculated from the main component's price minus the prices of SUS316L material content and imported spare parts, divided by the main component's price, as shown in equation (2).

$$
\begin{aligned}
& \text { TKDN }= \sum_{i=1}^{26} \frac{H E K U-H S C I-H M}{H E K U} \\
& \text { Where, } \\
& \text { HEKU }: \text { Main Component Estimation Price } \\
& \text { (Rp) } \\
& \text { i } \quad: \text { The main component to } \mathrm{i} \\
& \text { HSKI } \quad: \text { Spare Part Import Price (Rp) }
\end{aligned}
$$

Meanwhile, Method b) is used for pharmaceutical products, for instance, salt, in this case [11].

The TKDN process-based analysis is applied to the pharmaceutical industry in a bid to the lengthy and costly research and development process. This method's calculation is carried out based on four factors with respective numerical weights (BA), as shown below.

Table 1. Table ProcessBased Analysis Factors.

\begin{tabular}{clc}
\hline No & \multicolumn{1}{c}{ Factor } & $\begin{array}{c}\text { Weight } \\
\text { (BA) }\end{array}$ \\
\hline 1 & Raw Material & $50 \%$ \\
2 & Research \& Development (R\&D) & $30 \%$ \\
3 & Production Process & $15 \%$ \\
4 & Packaging Process & $5 \%$ \\
\hline
\end{tabular}

Each factor was classified by several criteria with respective numerical weight (AP). 
The numerical weight of raw material is determined based on the following criteria.

Table 2. Material Classification.

\begin{tabular}{lc}
\hline \multicolumn{1}{c}{ Item } & AP \\
\hline Active Raw Material & $65 \%$ \\
Additional Raw Material & $35 \%$ \\
\hline
\end{tabular}

The classification above ought to fulfill the production criteria comprising the following.

1) Labor from an Indonesian citizen.

2) Works tolls owned by a domestic company.

3) The material is locally sourced.

In addition, the production criteria were assessed based on the production origin and criteria. Tables 3 and $\mathbf{4}$ show the items and respective numerical weight (alo and kat).

Table 3. Production Origin.

\begin{tabular}{lc}
\hline \multicolumn{1}{c}{ Item } & alo \\
\hline All from domestic & $100 \%$ \\
One part from domestic & $65 \%$ \\
All from abroad & $0 \%$ \\
\hline
\end{tabular}

Table 4: Production Criteria.

\begin{tabular}{ll}
\hline \multicolumn{1}{c}{ Item } & \multicolumn{1}{c}{ kat } \\
\hline Only one factor is fulfilled & $\mathrm{i}=60 \%$ \\
Two factors factor are fulfilled & $\mathrm{i}=80 \%$ \\
All factors are fulfilled & $\mathrm{iii}=100 \%$ \\
Non-category & $\mathrm{iv}=40 \%$ \\
\hline
\end{tabular}

Table 5 shows the numerical weight and the research and development ( $R \quad \& \quad R \& D)$ processes.

Table 5: R\&D classification.

\begin{tabular}{lc}
\hline \multicolumn{1}{c}{ Item } & AP \\
\hline New drug development & $25 \%$ \\
Clinical test & $30 \%$ \\
Formulation & $35 \%$ \\
\hline
\end{tabular}

Tables 6 and 7 show the product origin and production criteria's items as well as numerical number weights for the research and development process, respectively.

Table 6: Production Origin.

\begin{tabular}{lc}
\hline \multicolumn{1}{c}{ Item } & alo \\
\hline All from domestic & $100 \%$ \\
One part from domestic & $65 \%$ \\
All from abroad & $0 \%$ \\
\hline
\end{tabular}

Table 7: Production Criteria.

\begin{tabular}{ll}
\hline \multicolumn{1}{c}{ Production criteria } & kat \\
\hline only one factor is fulfilled & $\mathrm{i}=80 \%$ \\
Two factors factor are fulfilled & $\mathrm{i}=100 \%$ \\
Non-category & $\mathrm{IV}=40 \%$ \\
\hline
\end{tabular}

Meanwhile, Table 8 shows the production process' item and numerical weight.

Table 8: Production Process Classification.

\begin{tabular}{lc}
\multicolumn{1}{c}{ Item } & AP \\
\hline Mixing Processes & $60 \%$ \\
Dosage Forming & $40 \%$ \\
\hline
\end{tabular}

Tables 9 and 10 show the product origin and production criteria's items and numerical weights, respectively.

Table 9: Production Origin.

\begin{tabular}{lc}
\hline \multicolumn{1}{c}{ Item } & alo \\
\hline All from domestic & $100 \%$ \\
One part from domestic & $65 \%$ \\
All from abroad & $0 \%$ \\
\hline
\end{tabular}

Table 10: Production Criteria.

\begin{tabular}{ll}
\hline \multicolumn{1}{c}{ Item } & kat \\
\hline Only one factor is fulfilled & $\mathrm{i}=80 \%$ \\
Two factors factor are fulfilled & $\mathrm{i}=100 \%$ \\
Non-category & $\mathrm{i}=40 \%$ \\
\hline
\end{tabular}

In addition, Table 11 shows the packaging process's items and numerical weight.

Table 11: Packaging Process Classification.

\begin{tabular}{lc}
\hline \multicolumn{1}{c}{ Item } & AP \\
\hline Batch release & $50 \%$ \\
Primary packaging & $40 \%$ \\
Secondary packaging & $10 \%$ \\
\hline
\end{tabular}

Tables 12 and 13 show the item and numerical number weight for the product origin and packaging process's production criteria, respectively.

Table 12: Production Origin

\begin{tabular}{lc}
\hline \multicolumn{1}{c}{ Item } & alo \\
\hline All from domestic & $100 \%$ \\
One part from domestic & $65 \%$ \\
All from abroad & $0 \%$ \\
\hline
\end{tabular}

Table 13: Production Criteria

\begin{tabular}{ll}
\hline \multicolumn{1}{c}{ Item } & kat \\
\hline only one factor is fulfilled & $\mathrm{i}=80 \%$ \\
Two factors factor are fulfilled & $\mathrm{i}=100 \%$ \\
Non-category & $\mathrm{i}=40 \%$ \\
\hline
\end{tabular}

The four factors at the pilot project and commercial stages ought to be assessed and classified based on the determination above while assessing the process-based analysis. Each classification also ought to be evaluated based on the product origin and the production criteria considerations. Thus, the process- 
based analysis TKDN calculation is the product of the multiplication between the respective numerical weight of factor (BA), classification (AP), production origin (alo), and production criteria (kat).

\section{RESULTS AND DISCUSSION}

The price of goods comprises the value of goods and services, including material, labor, and indirect costs (factory overhead). In this study, profits, company overhead, and output taxes were included in the calculation, assuming the ratio is infinitesimal compared to the finished good's price.

\section{Salt Factory at the Pilot Project Stage}

Table 14 shows each component's TKDN and TKLN ratio of each component, where $100 \%$ of the TKLN is known to be contained by the salt factory's 27 main components alone.

Table 14: TKDN \& TKLN Ratio.

\begin{tabular}{lrr}
\hline Item & TKDN & TKLN \\
\hline R\&D & $100 \%$ & $0 \%$ \\
Main component & $0 \%$ & $100 \%$ \\
Human Resources & $100 \%$ & $0 \%$ \\
Civil Buildings & $100 \%$ & $0 \%$ \\
Land & $100 \%$ & $0 \%$
\end{tabular}

Meanwhile, Table 15 shows the TKDN and TKLN, calculated based on each component's price, compared to the pilot project's total investment, indicating the factory has a TKDN of $27.4 \%$. This value was low due to the TKLN value of about $75 \%$, as the main component being imported from China. Thus, the salt factory's main components at the pilot project stage were all imported, and the TKDN was $27.4 \%$.

Table 15: TKDN and TKLN Value.

\begin{tabular}{lrr}
\hline Item & TKDN & TKLN \\
\hline R\&D & $3.2 \%$ & $0 \%$ \\
Main component & $0 \%$ & $72.6 \%$ \\
Human Resources & $3.3 \%$ & $0 \%$ \\
Civil Buildings & $13.8 \%$ & $0 \%$ \\
Land & $7.9 \%$ & $0 \%$ \\
\hline Total & $27.4 \%$ & $72.6 \%$ \\
\hline
\end{tabular}

\section{Salt Factory at the Commercial Stage}

Table 16 shows the TKDN and TKLN ratio components, where the R\&D, human resources, civil building, and land price components have the same ratio of $100 \%$. Thus, the 27 main components comprise $75.9 \%$ TKDN and $24.1 \%$ TKLN. The TKLN indicates the ratio of the main components domestic manufacturers are unable to produce. However, the main component's transportation costs in the TKLN were neglected because the ratio was minute, compared to the price.

Table 16: TKDN and TKLN Ratio.

\begin{tabular}{lrr}
\hline Item & TKDN & \multicolumn{1}{r}{ TKLN } \\
\hline R \& D cost & $100 \%$ & $0 \%$ \\
Main component & $75.9 \%$ & $24.1 \%$ \\
Human Resources & $100 \%$ & $0 \%$ \\
Civil Building & $100 \%$ & $0 \%$ \\
Land Price & $100 \%$ & $0 \%$ \\
\hline
\end{tabular}

Furthermore, Table 17 shows the salt factory's TKDN increased to $70.9 \%$ at the commercial stage. This was because 26 of the factory's main components are manufactured domestically. However, the R \& D components, human resources, civil buildings, and land had the TKLN value as the pilot project stage.

Table 17: TKDN and TKLN, at the Commercial Stage.

\begin{tabular}{lrr}
\hline Item & TKDN & \multicolumn{1}{c}{ TKLN } \\
\hline R \& D cost & $3.2 \%$ & $0 \%$ \\
Main component & $42.7 \%$ & $18.1 \%$ \\
Human Resources & $3.3 \%$ & $0 \%$ \\
Civil Building & $13.8 \%$ & $0 \%$ \\
Land Price & $7.9 \%$ & $0 \%$ \\
\hline Total & $70.9 \%$ & $18.1 \%$ \\
\hline
\end{tabular}

Salt Production at the Pilot Project and Commercial Stages.

Table 18 shows the raw material factor's calculation result to be $50 \%$.

Table 18: Raw Material Factor Value.

\begin{tabular}{lrrrrr}
\hline \multicolumn{1}{c}{ Item } & AP & Alo & Kat & BA & Value \\
\hline Active & $65 \%$ & 100 & 100 & $50 \%$ & $32.5 \%$ \\
& & $\%$ & $\%$ & & \\
Additiona & $35 \%$ & 100 & 100 & $50 \%$ & $17.5 \%$ \\
I & & $\%$ & $\%$ & & \\
Total & & & & & $50.0 \%$ \\
\hline
\end{tabular}

Meanwhile, Table 19 shows the research and development $(R \& D)$ factor to be $18.0 \%$.

Table 19: R\&D Factor.

\begin{tabular}{lllllc}
\hline Item & AP & Alo & Kat & BA & Value \\
\hline New Drug & 25 & 100 & 100 & $30 \%$ & $7.5 \%$ \\
& $\%$ & $\%$ & $\%$ & & \\
Formulati & 35 & 100 & 100 & $30 \%$ & $10.5 \%$ \\
on & $\%$ & $\%$ & $\%$ & & \\
\hline Total & & & & & $18.0 \%$ \\
\hline
\end{tabular}


Table 20 shows the production process factor calculation result to be $15.0 \%$.

Table 20: Production Process Factor.

\begin{tabular}{lcllrc}
\hline Item & AP & Alo & Kat & BA & Value \\
\hline Mixing & $60 \%$ & $100 \%$ & $100 \%$ & $15 \%$ & $9.0 \%$ \\
Dosage & $40 \%$ & $100 \%$ & $100 \%$ & $15 \%$ & $6.0 \%$ \\
forming & & & & & $15.0 \%$ \\
Total & & & & & \\
\hline
\end{tabular}

Meanwhile, Table 21 shows the packaging process calculation results to be $2.5 \%$.

Table 21: Packaging Process Factor.

\begin{tabular}{llllll}
\hline Item & AP & Alo & Kat & BA & Value \\
\hline Primary & $40 \%$ & 100 & 100 & $5 \%$ & $2.0 \%$ \\
Second & & $\%$ & $\%$ & & \\
ary & $10 \%$ & 100 & $80 \%$ & $5 \%$ & $0.5 \%$ \\
\hline Total & & & & & $2.5 \%$ \\
\hline
\end{tabular}

Table 22 shows the salt production's TKDN value at the pilot project and commercial stages to be $85.5 \%$.

Table 22: TKDN of Salt Production at the Pilot Project

\begin{tabular}{lr}
\hline Item & $\begin{array}{l}\text { Total } \\
\text { Value }\end{array}$ \\
\hline Raw Material Content & $50 \%$ \\
Research \& Development & $18 \%$ \\
Process Production & $15 \%$ \\
Packaging Process & $2.5 \%$ \\
\hline TKDN value & $85.5 \%$ \\
\hline
\end{tabular}

\section{Discussion}

In the pilot project stage, no domestic manufacturer was able to manufacture the main components for a limited time at the pilot project stage, therefore, the procurement of all main components comprising the 27 main components imported from Chinese manufacturers. Meanwhile, Table 1 indicates the human resources, building and civil facilitie's constructions, as well as land, were domestic. Therefore, the 27 main component's TKDN is $0 \%$, while the R\&D, human resources, building, and civil facilitie's construction counterpart is $100 \%$. Table 2 shows the TKDN and TKLN to be $27.4 \%$ and $72.6 \%$, respectively, using a comparison of each component's price with the total investment.

Subsequently, an investigation was conducted regarding the main component domestic supplier's ability to build the salt factory in salt production centers, and the following conclusions were attained.

a) Domestic manufacturers are unable to produce only one main equipment component.

b) SUS316L material, as a corrosiveresistant material and the main component material, remains imported goods and is not produced by domestic manufacturers.

c) Several electronic components/sensors, electric motors, and some control devices are currently not produced by domestic manufacturers and are therefore imported.

The first conclusion shows only one main component has a $0 \%$ TKDN ratio because the component is imported and not manufactured by any domestic supplier. Based on the developer team's interview, this main component is a critical component used in the salt factory's technology to increase $\mathrm{NaCl}$ content.

Meanwhile, the second conclusion shows domestic manufacturer's main components (26 components) ought to be separated backwards, up to the second layer. The 26 main components of imported material are known to be SUS316L material; thus, there is a need to know the SUS316L material content's price. To determine this price, each main component's SUS316L volume content was calculated by multiplying with the SUS316L density (BJ) and market price, as shown in equation (1). This material price comprises a material, labor, and indirect costs (factory overhead).

For the third conclusion, in addition to the SUS316L's material content, the price of imported spare parts such as sensor components, electric pumps, controls are also analyzed and estimated.

Based on Table 17, the salt factory's TKDN increased to $70.9 \%$ at the commercial stage due to one main component, and all SUS316L material is imported. Meanwhile, Tables 16 and 17 show the TKLN ratio and values are $24.1 \%$ and $18.1 \%$, respectively.

\section{Salt Production at the Pilot Project and Commercial Stages.}

The salt raw material used at the pilot project and commercial stages is local salt.

In the raw material assessment, $\mathrm{BA}=50 \%$, the calculation result value of a raw material factor is $50 \%$, calculated from the sum of active raw material, $\mathrm{AP}=65 \%$, and additional raw material, $\mathrm{AP}=35 \%$. In addition, a local salt factory produces both the active and additional raw material, alo $=100 \%$; thus all production 
criteria are fulfilled, and kat $=100 \%$. Salt possesses pharmacological properties and is therefore regarded as an active material. A study by Nuryati [12] also shows salt impacts the human body upon entering the bloodstream. Meanwhile, water has no pharmacological effect and is therefore regarded as a raw material. Therefore, improving salt quality through the refining process is considered as new drug development, $\mathrm{AP}=25 \%$ and the new formulation development, $\mathrm{AP}=35 \%$ to increase $\mathrm{NaCl}$ content to $98 \%$.

Based on these considerations, the R\&D process factors, $B A=30 \%$, comprises the new drug development and formulation processes. Each process factor's numerical weight is multiplied by the domestic production's numerical weight, alo $=100 \%$, and the production criteria are fulfilled, kat $=100 \%$. Table 6 shows both calculations produced a total of $18 \%$.

In the production process, $B A=15 \%$, two processes are determined based on the following considerations. Active (salt) and additional (water) raw materials are mixed, then evaporated to obtain salt crystals. This is considered as the mixing process, AP $=60 \%$. Meanwhile, the dosage forming process, $\mathrm{AP}=40 \%$, is the process of forming drugs, and in this case, the salt is ready to be marketed. Therefore, each production factor's numerical weight is multiplied by the domestic production's numerical weight, alo $=100 \%$, and the production criteria are fulfilled, kat $=100 \%$. Table 7 shows both calculations gave a total of $15 \%$.

In the packaging process, $B A=5 \%$, two processes are determined based on the following considerations. The primary packaging process refers to packaging in contact with pharmaceutical ingredients/salt, while the secondary counterpart, $\mathrm{AP}=40 \%$, refers to complementary packaging from the primary process. Each packaging process is conducted in domestic development (alo = $100 \%$ ), and the production criteria are fulfilled, kat $=100 \%$. Table 8 shows each numerical weight's multiplied result is $2.5 \%$.

Meanwhile, Table 9 shows the TKDN is the sum of multiplied results from each factor, with a value of $85.5 \%$. This result is relatively high, indicating domestic manufacturers have a significantly high ability for salt production.
According to the description above, the conditions for making industrial salt, from the process-based analysis at the pilot project and the commercial stages, were in the same condition. The total TKDN indicates the same value of $85.5 \%$. The salt factory's main components at the pilot project stage were the import components, and a domestic company owned the imported component's owner. Thus, both conditions did not reduce the assessment value's allocation of $100 \%$.

\section{CONCLUSION}

The salt factory's good and service's TKDN value from the cost- and process-based analyses indicates the factory's use of technology to increase $\mathrm{NaCl}$ content to $98 \%$ currently depends on the imported main component. In addition, the salt factory development at the commercial stage is estimated to increase the TKDN value to $70.9 \%$. However, a further increment is not possible because one main component and the main SUS316L component's material are not produced by domestic manufacturers due to inadequate technical capability for fabrication. Thus, the cost-based analysis TKDN is strongly influenced by the salt factory equipment/component's origin. It was revealed by the TKDN assessment of the salt factory at the pilot project stage and at the commercial stage, which increased the local content of the main components from $27.4 \%$ to $70.9 \%$.

However, the salt production assessed by the process-based analysis obtained a high value of $85 \%$ and based on this result, salt production was concluded to be completely carried out domestically. The assessment indicates raw materials, research, and development, production, as well as packaging processes are significantly influenced by Indonesian workers, work tools owned by domestic companies, and local materials.

This study, therefore, showed a rise in domestic component content increases the domestic manufacturers/industrie's capacity to support spare parts and maintenance procurement.

\section{AUTHOR INFORMATION}

\section{Corresponding Authors}

Email: irhan.febijanto@gmail.com.

Phone: +6281121303020. 


\section{Author Contribution}

The first author calculated and analyzed the TKDN for salt and salt production, while the other author contributed to data collection, information, and component price analysis.

\section{ACKNOWLEDGMENT}

The authors are grateful to the development team from the Center for Technology for the Development of Energy Resources and the Chemical Industry (PTSEIK)'s Integrated Salt Factory for providing support information and discussion, regarding the salt factory and salt production, during the TKDN assessment.

\section{REFERENCES}

[1] Pujiastuti, C., Sumada, K., Ngatilah, Y., Hadi, P., Removal of Mg2+, $\mathrm{K}+$, SO4-2 Ions from Seawater by Precipitation Method, MATEC Web of Conference 58, 01022, 2016, BISSTECH.

[2] Pangestu, R.G., Perlindungan hukum terhadap petambak garam rakyat dikaitkan dengan berlakunya peraturan pemerintah nomor 9 tahun 2018 tentang tata cara pengendalian impor untuk komoditas perikanan dan penggaraman sebagai bahan baku dan bahan penolong industri, Dialogia Juridica, 10(1), November 2018, pp.077-095.

[3] Mayasari, V.A., dan Lukman, R., Studi peningkatan mutu garam dengan pencucian, 2011, rosihttp://digilib.its.ac.id/public/ITSUndergraduate-10536-Paper.pdf, diakses tanggal 6 Oktober 2020.
[4] Sumada, K., Dewati, R., Suprihatin, Garam industri berbahan baku garam krosok dengan metode pencucian dan evaporasi, Jurnal Teknik Kimia, 11(1), 2016.

[5] Umam, F., Pemurnian garam dengan metode rekristalisasi di desa bunder pamekasan untuk mencapai SNI garam dapur, Jurnal Pangabdhi, 5(1), 2019, pp. 24-27.

[6] Windaru, A., Budiman, A.H., 2017. Analisa biaya pembangkitan pembangkit listrik tenaga panas bumi skala kecil, Jurnal Energi dan Lingkungan, 13(2), 2017, pp. 47-50.

[7] Sucahyo, B., Hakim, D.L., Ridlo, R., Rini, T.P., Sari, E.R., 2019. Kajian Teknologi Pemanfaatan Biogas POME (Palm Oil Mill Effluent) ke Boiler, Majalah IImiah Pengkajian Industri, 13(1), 2019, pp.43-54.

[8] Hidayat, T., and Ma'ruf,. B, Analisis Peningkatan Kandungan Komponen Lokal pada Pembangunan Kapal Baru di dalam Negeri, Jurnal Wave, Vol 10 No 2, 2016, pp.61-66.

[9] Peraturan Menteri Perindustrian Republik Indonesia Nomor: 16/M-IND/PER/2/2011 Tahun 2011 tentang Ketentuan dan Tata Cara Penghitungan Tingkat Komponen Dalam Negeri.

[10] Peraturan Menteri Perindustrian Republik Indonesia Nomor 16 tahun 2020 tentang Ketentuan dan Tata Cara Penghitungan Nilai Tingkat Komponen Dalam Negeri Produk Farmasi.

[11] Tansil, Y., Belina, Y., Widjaja, T., Produksi garam farmasi dari garam rakyat, Jurnal Teknik ITS, 5(2), 2016, ISSN: 23373539 (2301-9271 Print)

[12] Nuryati, Farmakologi: Bahan Ajar Rekam Medis dan Informasi Kesehatan, Pusat Pendidikan Sumberdaya Manusia Kesehatan, Kementerian Kesehatan Republik Indonesia, Cetakan ke 1. 2017. 